\title{
Impact of the coastal taiga fires onto chemical elemental composition of soils, grounds and near-shore waters of Bol'shoy Ushkaniy Island (Lake Baikal, Siberia)
}

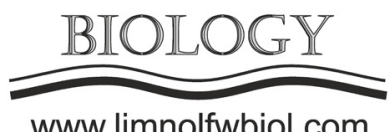

www.limnolfwbiol.com

\author{
Kulikova N.N. ${ }^{1 *}$, Chebykin E.P. ${ }^{1}$, Suturin A.N. ${ }^{1}$, Vashukevich N.V. ${ }^{2}$, Timoshkin O.A. ${ }^{1}$ \\ ${ }^{1}$ Limnological Institute of the Siberian Branch of RAS, Ulan-Batorskaya Str., Irkutsk, 3664033, Russia \\ ${ }^{2}$ Ural State Agrarian University, Karl Liebknecht Str., 42, Ekaterinburg, 620075, Russia
}

\begin{abstract}
In order to study the chemicals drainage into the lake near-shore zone from burnt out forest territories by ICP-MS method, we determined elemental composition of soils from forest territories in the shore zone on Bol'shoy Ushkaniy Island, which were damaged by the fire, which were not damaged by the fire, of ash from burnt anthills, of grounds and water of near-shore zone adjacent to sites of burnt forest and of forest site, which was not burnt (background one). The research found out that the shore zone with damaged by fire vegetation and soil cover and burnt anthills, compared to background site, is a more abundant source of mobile chemical compounds, especially of $\mathrm{P}, \mathrm{S}, \mathrm{K}, \mathrm{Ca}, \mathrm{Mn}, \mathrm{Zn}, \mathrm{Mo}$, $\mathrm{Cd}, \mathrm{Ba}$. Their considerable part with surface flow and interflow migrate out of soil profile, accumulate temporarily in the base of shore scarp and are transferred gradually into the adjacent to the shore scarp zone of splash and further, into the lake shallow water zone.
\end{abstract}

Keywords: forest fires, post-fire soils, chemicals, near-shore zone, Lake Baikal

\section{Introduction}

During forest fires, vegetation cover is burnt completely or partly, the forest litter is destroyed, upper soils horizons are transformed. Under the conditions of comparatively slow reconstitution of vegetation at burnt sites and of erosion processes activation, there is a danger of washing out of considerable part of chemicals from ash and disturbed vegetation cover (Bryanin, 2014; Maximova and Abakumov, 2014). Many elements included in post-fire soils and ash are very mobile, they are readily transferred into a solution, are transferred with precipitations into lower soils horizons or migrate with surface flow and interflow down the slope, accumulate temporarily in the accumulating part of a landscape, then migrate out of it with thaw, rain and ground waters (Purtova et al., 2012). This migration results in gradual empoverishment of biogenic elements of elevated sites and in eutrofication of lowered relief forms (Sapozhnikov, 1976).

\section{Objects and methods}

Using ICP-MS method, we determined elemental composition of soil samples from two sites of pinelarch forest, which was burnt in 2015 in the northern part of Bol'shoy Ushkaniy Island (site of $290 \mathrm{~m}^{2}-$ with fragments of non-burnt vegetation and one of $100 \mathrm{~m}^{2}$ - without vegetation cover); samples of ash from anthills destroyed with the fire, soil samples of non-burnt forest site $\left(100 \mathrm{~m}^{2}\right)$ in the southern part of the island (Akademicheskaya Bay), as well as water and ground samples from the near-shore zone near forest fire extension and in the area of the background site. Soils were sampled in September, 2016 and in June, 2017 from the cross-sections, placed on the terrace area, on the shore scarp and in its basis. From holes on the beaches adjacent to selected forest sites, interstitial water and grounds were sampled; in $1 \mathrm{~m}$ below water line, water and bottom grounds were sampled. Water samples were filtered via membrane filters of acetyl cellulose with pores diameter of $0.2 \mu \mathrm{m}$, conserved with twice rectified $\mathrm{HNO}_{3}$ (analytical grade). Soils and grounds samples were dried at $30^{\circ} \mathrm{C}$, bolted, triturated in agate mortar, averaged samples were made by quartering method and dried up to constant weight at $105^{\circ} \mathrm{C}$. To determine elemental composition, dry sample weights were decayed in polypropylene test tubes with twice rectified acids $\mathrm{HNO}_{3}$ and $\mathrm{HF}$ (analytical grade).

The aim of the research is to determine the influence of forest fires onto geochemical characteristics of the sited of lake near-shore zone adjacent to burnt territories. 


\section{Results and discussion}

Stony, short-profile soils of background and postfire sites develop on carbonate rocks under pine-larch forests with motley grasses. In post-fire soils, the surface layer $0-2 \mathrm{~cm}$ thick is represented by ash or organicmineral mass with small carbons. Next pyrogenoushumus horizon with inclusions of ash, small carbons and carbonized plants debris passes into an illuvial horizon and from ca. $20 \mathrm{~cm}$ - into soil forming rock. In the background soil (forest litter) $-0-3 \mathrm{~cm}$; humus layer $-3-10 \mathrm{~cm}$, under it there is an illuvial horizon, 10-30 cm, below - a horizon wit $\mathrm{h}$ a large amount of pebbles and rock debris. Ash content of upper horizons of soil on the sites of forest fire is 70-86 \% (partly burnt out forest), 88-92\% (a site of burnt out forest). Ash content of these horizons in the soil of the background site is $39-46 \%$.

During the second year after the fire, we observed in the soil of selected sites from the upper horizon to soil forming rock a higher than in the background soils site content of $\mathrm{Li}, \mathrm{Be}, \mathrm{Na}, \mathrm{Al}, \mathrm{Si}, \mathrm{K}, \mathrm{Ti}, \mathrm{V}, \mathrm{Cr}, \mathrm{Fe}, \mathrm{Co}, \mathrm{Ni}, \mathrm{As}$, $\mathrm{Zr}$, major part of which is included in mineral matter of soils and accumulates passively due to leakage of other elements (Zhurkova and Shcherbov, 2016). Besides the accumulation of these elements, an intensive leakage of accumulated biogenic elements is observed. Horizons of post-fire soils laying under a thin layer of carbonized or burnt forest litter, compared to background soil, are impoverished with $\mathrm{Ca}, \mathrm{P}, \mathrm{S}$ and $\mathrm{Mn}$. Gradual decrease of the content of these elements with depth in the soil of partly damaged with fire forest is replaced by abrupt decrease of content of $\mathrm{Ca}, \mathrm{P}, \mathrm{S}$ and $\mathrm{Mn}$ in the soil profile of a burnt site. In the background soil, P, S and Mn are concentrated in the humus horizon, much $\mathrm{S}$ and $\mathrm{Ca}$ are accumulated and stored in the forest litter; maximal content of $\mathrm{Ca}$ and $\mathrm{Mg}$ is in the illuvial horizon and in the soil forming rock. Chemicals migrating with surface flow and interflow are accumulated in the soil in the basis of shore scarp and then are leaked into the nearshore zone of the lake with surface flow, interflow and ground flow.

In the island forest there are many large anthills destroyed with the fire, it determines another source of chemicals migrating with surface and ground flow into the near-shore zone. The elemental composition of anthills ash sampled during the first year after the fire is particular by a higher content of $\mathrm{P}, \mathrm{S}, \mathrm{K}$, Mo than in the soil. During the second year, the amount of $\mathrm{P}, \mathrm{Zn}$, Mo, Cd in the ash decreased ca. 3 times, and amount of $\mathrm{S}$ - more than 10 times. The decrease of their content in the ash and lower soil layer suggest the most intensive migration of these elements.

\section{Conclusions}

The research suggests that burnt forests sites in the island shore zone differ from the background territory by more intensive migration of numerous chemicals (especially of $\mathrm{P}, \mathrm{S}, \mathrm{K}, \mathrm{Ca}, \mathrm{Mn}, \mathrm{Zn}, \mathrm{Mo}, \mathrm{Cd}$, $\mathrm{Ba})$, which are leaked into the near-shore zone with surface and ground flow. Migration intensity increases with increase of burning degree of forest-covered territories.

\section{Acknowledgement}

Planning, setting aims and tasks, the annual material samplings were performed in the frames of the Federal Project: 0345-2019-0009 "Large-scale changes in ecology and biodiversity of communities in Lake Baikal near-shore zone: interdisciplinary research, causes revealing, development forecast"; sample preparation, determination of elemental composition using the ICP-MS method and data analysis was made in within State budgetary project: 0345-2019-0010 "Influence of changing natural and anthropogenic factors onto biogeochemical processes on Lake Baikal stony littoral".

\section{References}

Zhurkova I.S., Shcherbov B.L. 2016. Migration of chemicals during forest ground fire (Altay Land). Izvestiya Irkutskogo Gosudarstvennogo Universiteta. Seriya "Nauki o Zemle" [The Bulletin of Irkutsk State University. Series "Earth Sciences"] 16: 30-41. (in Russian)

Maximova Ye.Yu., Abakumov Ye.V.2014. Ash composition of upper horizons and basic biological parameters of soil in Tolyatti island pine forest and changes in them due to forest fires impact. Vestnik Sankt-Peterburgskogo Universiteta. Biologiya [The Bulletin of Saint-Petersburg University. Biological Communications] 3: 132-143. (in Russian)

Bryanin S.V. 2014. Migration and accumulation of ash constituents in forest landscapes under the influence of periodic fires on Amur-Zeya valley. Fundamental'nyye Issledovaniya [Basic Research] 8: 859-863. (in Russian)

Purtova L.N., Kostenkov N.M., Bryanin S.V. 2012. Influence of forest fires onto humus-energy state of brown soils in Pre-Amur. Byulleten' Krasnoyarskogo Gosudarstvennogo Agrarnogo Universiteta [Bulletin of Krasnoyarsk State Agrarian University] 5: 121-124. (in Russian)

Sapozhnikov A.P. 1976. The role of fire in soils formation. Ekologiya [Ecology] 1: 42-46. (in Russian) 